\title{
Comparison of Nitrification Rates in Blueberry and Forest Soils
}

\author{
Eric J. Hanson, ${ }^{1}$ Philip A. Throop, ${ }^{2}$ Sedat Serce, ${ }^{3}$ John Ravenscroft, ${ }^{4}$ and Eldor A. Paul ${ }^{5}$ \\ Department of Horticulture, Michigan State University, East Lansing, MI 48824-1325
}

\begin{abstract}
AdDITIONAL INDEX WORDs. nitrate, ammonium, isotopes, mineralization, nitrogen, fertilization, Vaccinium corymbosum
Abstract. Highbush blueberries (Vaccinium corymbosum L.) are long lived perennial plants that are grown on acidic soils. The goal of this study was to determine how blueberry cultivation might influence the nitrification capacity of acidic soils by comparing the nitrification potential of blueberry soils to adjacent noncultivated forest soils. The net nitrification potential of blueberry and forest soils was compared by treating soils with ${ }^{15} \mathrm{~N}$ enriched $\left(\mathrm{NH}_{4}\right)_{2} \mathrm{SO}_{4}$, and monitoring nitrate $\left(\mathrm{NO}_{3}{ }^{-}-\mathrm{N}\right)$ production during a 34-day incubation period in plastic bags at $18{ }^{\circ} \mathrm{C}$. Net nitrification was also compared by an aerobic slurry method. Autotrophic nitrifiers were quantified by the most probable number method. Nitrate production from labeled ammonium $\left({ }^{15} \mathrm{NH}_{4}^{+}\right)$indicated that nitrification was more rapid in blueberry soils than in forest soils from six of the seven study sites. Slurry nitrification assays provided similar results. Blueberry soils also contained higher numbers of nitrifying bacteria compared to forest soils. Nitrification in forest soils did not appear to be limited by availability of $\mathrm{NH}_{4}{ }^{+} \mathrm{substrate}$ Results suggest that blueberry production practices lead to greater numbers of autotrophic nitrifying bacteria and increased nitrification capacity, possibly resulting from annual application of ammonium containing fertilizers.
\end{abstract}

Nitrification, the oxidation of ammonium $\left(\mathrm{NH}_{4}{ }^{+}\right)$to nitrate $\left(\mathrm{NO}_{3}\right)$, is an important soil process that can affect fertilizer use efficiency, the potential for $\mathrm{NO}_{3}{ }^{-}$movement into potable water sources, and loss of $\mathrm{N}_{2} \mathrm{O}$ to the atmosphere as a global warming gas (Robertson et al., 2000). Autotrophic bacteria are the primary nitrifiers in most soils. Although these bacteria have been thought to be inhibited by low pH (Watson, 1974), and acidic soils usually exhibit low nitrification rates (Dancer et al., 1973: Morrrill and Dawson, 1967), some acidic soils have relatively high nitrification rates. High nitrification in acidic soils has been attributed variously to acid tolerant autotrophic bacteria (DeBoer et al., 1990), nitrifying heterotrophic organisms (Stroo et al., 1986), or acid sensitive autotrophs that function within high $\mathrm{pH}$ microsites in the acidic soils (Hankinson and Schmidt, 1984) or by forming protective cell aggregates (DeBoer et al., 1991).

Highbush blueberries (Vaccinium corymbosum) require acid soils (optimum $\mathrm{pH} 4.5$ to 5.0) and are usually grown on coarse textured, well drained soils where $\mathrm{NO}_{3}{ }^{-}$may be prone to leaching. The fact that blueberries absorb $\mathrm{NO}_{3}{ }^{-}$less readily than $\mathrm{NH}_{4}{ }^{+}$ (Peterson et al., 1988) may further increase the potential for $\mathrm{NO}_{3}^{-}$ leaching. Nitrate may be toxic to blueberries under some conditions (Herath and Eaton, 1968). Although nitrification could impact fertilizer use efficiency and the potential for $\mathrm{NO}_{3}{ }^{-}$contamination of water, information on $\mathrm{NO}_{3}{ }^{-}$generation in blueberry soils is limited. Fertilizer $\mathrm{NH}_{4}{ }^{+}$was nitrified at a moderate rate in one blueberry field study, but this soil had an atypically high $\mathrm{pH}$ that was reduced by $\mathrm{S}$ additions (Throop and Hanson, 1998).

Ammonium fertilizer applications appeared to increase the nitrification capacity in native stands of lowbush blueberry (Eaton and Patriquin, 1988) and in annual crop production on loam soils (Tabatabai et al., 1992). Annual applications of $\mathrm{NH}_{4}-\mathrm{N}$ up to 70

Received for Publication 16 Apr. 2001. Accepted for publication 19 Sept. 2001. Acknowledgment is made to the Michigan Agricultural Experiment Station for support of this work. The cost of publishing this paper was defrayed in part by the payment of page charges. Under postal regulations, this paper therefore must be hereby marked advertisement solely to indicate this fact.

'Professor and corresponding author; e-mail hansone@msu.edu.

${ }^{2}$ Research technician, Department of Horticulture.

${ }^{3}$ Research assistant, Department of Horticulture.

${ }^{4}$ Research assistant, Department of Crop and Soil Science.

${ }^{5}$ Professor, Department of Crop and Soil Science. $\mathrm{kg} \cdot \mathrm{ha}^{-1}$ are recommended for blueberries in Michigan (Hanson and Hancock, 1996), and many older plantings have received fertilizer for decades. A preliminary study comparing $\mathrm{NO}_{3}{ }^{-}$production in Michigan blueberry soils to that of similar soils from adjacent noncultivated forest areas (Hanson and Mandujano, 1997) indicated that blueberry soils nearly always produced $\mathrm{NO}_{3}{ }^{-}$at higher rates (mean $0.074 \mu \mathrm{g} \mathrm{NO}_{3}-\mathrm{N} / \mathrm{g}$ soil per d) than adjacent forest soils $(0.032$ $\mu \mathrm{g} \mathrm{NO}_{3}-\mathrm{N} / \mathrm{g}$ soil per day). However, the blueberry soils also contained higher $\mathrm{NH}_{4}{ }^{+}$levels, so it was not clear whether more $\mathrm{NO}_{3}{ }^{-}$ was produced because the pool of $\mathrm{NH}_{4}{ }^{+}$substrate was larger or if there was greater nitrification capacity due to other factors. Therefore, the objective of the current study was to determine if previously reported differences in $\mathrm{NO}_{3}{ }^{-}$production (Hanson and Mandujano, 1997) were due to differences in $\mathrm{NH}_{4}{ }^{+}$substrate availability or nitrifier populations and inherent nitrification capacity.

\section{Materials and Methods}

Soils chosen for this experiment exhibited either high or low nitrification potentials and a wide range in $\mathrm{pH}$ (3.5 to 5.7) as determined in a previous study (Hanson and Mandujano, 1997). Soils were sampled on 9 Sept. 1996 from seven blueberry plantings and adjoining noncultivated forest areas. Four plantings were in Van Buren County, Mich., and were classified as either as PipestoneKingsville complex (sandy mixed mesic Typic Endoaquad, mixed, mesic Mollic Psammaquents) (sites $\mathrm{CH} 1, \mathrm{CH} 2$, and MB) or Morocco loamy sand (mixed mesic Aquic Udipsamments) (site KO). Three sites (GR1, GR2, and DE) were in Ottawa County, Mich., and mapped as Au-Gres Saugatuck complex loamy sands (sandy mixed frigid Typic Endoaquad, sandy, mixed, shallow, ortstein Typic Duraquad). Blueberry sites had been in production for 18 years or more. Although the forested areas may have been cultivated at some time, estimated tree age indicated that they had not been cultivated for at least 30 years (CH1, CH2, and GR2 sites), or 60 years (DE, $\mathrm{GR} 1, \mathrm{KO}$, and MB sites). Forested sites contained mixed stands of hardwood species. The sampling areas were selected so that the blueberry fields and forest areas bordered one another and shared a similar soil type. Sampling areas varied from 50 to $200 \mathrm{~m}$ in length and 20 to $40 \mathrm{~m}$ in width.

LABELED N Nitrification. On 9 Sept. 1996, twenty $20 \mathrm{~cm}$ deep soil cores were collected with a $2.5 \mathrm{~cm}$ diameter soil probe through- 
out each sampling area, usually by walking a staggered pattern across rows or through woods. The 20 soil cores were mixed in buckets, placed in 4-L plastic bags in an ice chest, transported to East Lansing, Mich., and placed in a cooler at $2^{\circ} \mathrm{C}$. Soil moisture content and water holding capacity (WHC) were determined for each soil so that the moisture content could be adjusted to $50 \%$ of WHC for the incubation study. Field moisture contents were determined by weighing subsamples of each soil before and after drying for $24 \mathrm{~h}$ at $60{ }^{\circ} \mathrm{C}$ in a forced air oven. WHC was determined by placing $30 \mathrm{~g}$ of dry soil in a funnel containing previously weighed filter paper. The soil was saturated with water, and allowed to drain for $3 \mathrm{~h}$. The soil and filter paper were then weighed and the WHC was calculated as the difference between the dry and drained weight of soils minus that of the filter paper.

On 26 Sept. 1996, fresh soil, equivalent to $200 \mathrm{~g}$ dry weight, was placed in 4-L polyethylene bags. Each bag was treated with $30 \mathrm{mg}$ $\left(\mathrm{NH}_{4}\right)_{2} \mathrm{SO}_{4}$ enriched to 99.8 atom $\%{ }^{15} \mathrm{~N}$ (Isotec, Inc., Miamisburg, Ohio) by spraying $\left(\mathrm{NH}_{4}\right)_{2} \mathrm{SO}_{4}$ solutions with a hand sprayer over the bagged soil. The bags were shaken at least three times during the application to evenly distribute the $\mathrm{N}$. The tracer was applied in enough water to bring each soil to $50 \% \mathrm{WHC}$. The application rate ( $\mathrm{N}$ at $33.5 \mu \mathrm{g} \cdot \mathrm{g}^{-1}$ dry soil) was equivalent to an application of $\mathrm{N}$ at $73.4 \mathrm{~kg} \cdot \mathrm{ha}^{-1}$ (assuming a 2,200,000 kg soil/ha furrow slice, $17 \mathrm{~cm}$ depth). Three bags of each soil served as replications. Bags were closed, and incubated at $18{ }^{\circ} \mathrm{C}$ in the dark. Bags were weighed weekly and water was added when needed to maintain the moisture content at $50 \%$ of WHC.

Subsamples were removed from each bag for N analyses 5, 8, 17, and $34 \mathrm{~d}$ after treatment, and extracted by shaking a suspension of $10 \mathrm{~g}$ soil in $75 \mathrm{~mL}$ of $1 \mathrm{M} \mathrm{KCl}$ at $150 \mathrm{rpm}$ on a solution agitator (New Brunswick Scientific Co., Edison, N.J.) for $45 \mathrm{~min}$. The extracts were passed through Whatman no. 5 filter paper, which had been rinsed previously with deionized water, and analyzed for total $\mathrm{NO}_{3}{ }^{-}$ -N and $\mathrm{NH}_{4}{ }^{+}-\mathrm{N}$ with a Lachat Instruments autoanalyzer and Quikchem methods 12-107-06-1-A and 12-107-04-1-F (Lachat, Milwaukee, Wis).

A sequential diffusion procedure (Brooks et al., 1989) was used to separate the $\mathrm{NH}_{4}{ }^{+}-\mathrm{N}$ from $\mathrm{NO}_{3}{ }^{-} \mathrm{N}$ in the extracts. The extracts were first treated with $\mathrm{MgO}$ to raise $\mathrm{pH}$ and convert $\mathrm{NH}_{4}{ }^{+}-\mathrm{N}$ to $\mathrm{NH}_{3}$ gas. The gas was condensed on Whatman no. 3 filter paper disks treated with $\mathrm{K}_{2} \mathrm{SO}_{4}$ and $\mathrm{H}_{2} \mathrm{SO}_{4}$. Devardas alloy with $50 \mu \mathrm{L}$ of surfactant per sample cup was then used to convert $\mathrm{NO}_{3}{ }^{-} \mathrm{N}$ to $\mathrm{NH}_{3}$ gas, which condensed on new treated disks. The ${ }^{15} \mathrm{~N}$ enrichment of the $\mathrm{NH}_{4}{ }^{-}-\mathrm{N}$ and $\mathrm{NO}_{3}{ }^{-}-\mathrm{N}$ fractions was determined by mass spectrometry using a Europa Scientific (Crewe, England) Tracer Mass instrument (Harris and Paul, 1989). Sample discs were arranged according to concentrations to avoid errors due to carryover and drift as samples were analyzed with the mass spectrometer. Reference ${ }^{15} \mathrm{~N}$ standards were included after every 12 samples.

Total soil $\mathrm{N}$ and atom $\%{ }^{15} \mathrm{~N}$ were measured after $34 \mathrm{~d}$ of incubation by analyzing $10 \mathrm{mg}$ samples of dry soil with a commercial C-N analyzer-continuous flow isotope ratio mass spectrometer (Europa Scientific, Crewe, England) (Harris and Paul, 1989). The percentage of total $\mathrm{N}$ (inorganic and organic) originating from the fertilizer (NFF) was calculated as follows: $\mathrm{NFF}=100(\mathrm{~A}-\mathrm{B}) /(\mathrm{C}-\mathrm{B})$, where $\mathrm{A}=$ atom $\%{ }^{15} \mathrm{~N}$ of sample, $\mathrm{B}=$ atom $\%{ }^{15} \mathrm{~N}$ ambient $(0.366 \%)$, and $\mathrm{C}=$ atom $\%{ }^{15} \mathrm{~N}$ in fertilizer $(99.8 \%)$. Organic fertilizer $\mathrm{N}$ was calculated by subtracting the sum of inorganic fertilizer $\mathrm{N}\left(\mathrm{NO}_{3}{ }^{-}-\mathrm{N}\right.$ and $\mathrm{NH}_{4}{ }^{+}-\mathrm{N}$ determined by sequential diffusion as described previously) from the total fertilizer N. Organic matter content was measured by loss of weight on ignition at $360{ }^{\circ} \mathrm{C}$ (Combs and Nathan, 1998). Soil organic $C$ was estimated by dividing the organic matter content by 1.724(Nelson and Sommers, 1982). The C:N ratio was computed by dividing the organic $\mathrm{C}$ concentration by the total soil $\mathrm{N}$ concentration. Three replicate samples of each soil were analyzed for Bray-Kurtz-1 extractable $\mathrm{P}$, ammonium acetate extractable $\mathrm{Ca}, \mathrm{Ma}$, and $\mathrm{K}$ and $\mathrm{pH}$ in a 1 soil/water slurry (by volume). Particle size analyses of single samples of each soil were conducted by the hydrometer method.

SLURRY NITRIFICATION. Additional forest and blueberry soil was collected from the $\mathrm{CH} 1, \mathrm{CH} 2, \mathrm{GR} 1, \mathrm{MB}$, and $\mathrm{KO}$ sites on $7 \mathrm{Sept}$. 1999 , using the same sampling procedure as in 1996. Soil nitrification potentials were determined by a shaken slurry method (Hart et al., 1994). After subsamples were taken from each soil for moisture

Table 1. Chemical and physical characteristics of soils collected in 1996 from blueberry fields and adjacent forest sites on seven southern Michigan farms. Organic matter, $\mathrm{pH}$, and $\mathrm{P}, \mathrm{K}, \mathrm{Ca}$, and $\mathrm{Mg}$ concentrations are means of three observations. Particle analysis data are single measurements.

\begin{tabular}{|c|c|c|c|c|c|c|c|c|c|c|}
\hline \multirow{2}{*}{$\begin{array}{l}\text { Study } \\
\text { site }^{\mathrm{z}}\end{array}$} & \multirow[b]{2}{*}{ Cropping } & \multirow[b]{2}{*}{$\mathrm{pH}$} & \multirow{2}{*}{$\begin{array}{c}\text { Organic } \\
\text { matter } \\
(\%)\end{array}$} & \multicolumn{4}{|c|}{$\begin{array}{l}\text { Mineral nutrient } \\
\left(\mathrm{mg} \cdot \mathrm{kg}^{-1}\right)\end{array}$} & \multicolumn{3}{|c|}{ Particle analysis $(\%)$} \\
\hline & & & & $\mathrm{P}$ & $\mathrm{K}$ & $\mathrm{Ca}$ & $\mathrm{Mg}$ & Sand & Silt & Clay \\
\hline$\overline{\mathrm{CH} 1}$ & Blueberry & 4.2 & 3.9 & 106 & 40 & 232 & 52 & 87 & 9 & 4 \\
\hline $\mathrm{CH} 1$ & Forest & 4.4 & 3.6 & 9 & 15 & 48 & 21 & 82 & 4 & 4 \\
\hline $\mathrm{CH} 2$ & Blueberry & 4.4 & 4.3 & 140 & 50 & 143 & 32 & 83 & 10 & 7 \\
\hline $\mathrm{CH} 2$ & Forest & 4.9 & 4.8 & 52 & 35 & 381 & 37 & 88 & 8 & 4 \\
\hline $\mathrm{DE}$ & Blueberry & 4.6 & 7.8 & 70 & 35 & 334 & 200 & 87 & 7 & 6 \\
\hline DE & Forest & 4.2 & 5.4 & 27 & 25 & 143 & 42 & 89 & 7 & 4 \\
\hline GR1 & Blueberry & 5.2 & 3.6 & 117 & 40 & 428 & 105 & 89 & 7 & 4 \\
\hline GR1 & Forest & 4.4 & 4.7 & 9 & 20 & 48 & 27 & 90 & 6 & 4 \\
\hline GR2 & Blueberry & 5.3 & 4.9 & 160 & 40 & 428 & 120 & 90 & 5 & 5 \\
\hline GR2 & Forest & 4.7 & 4.7 & 10 & 25 & 286 & 84 & 90 & 6 & 4 \\
\hline $\mathrm{KO}$ & Blueberry & 4.2 & 3.4 & 22 & 85 & 192 & 69 & 77 & 13 & 10 \\
\hline $\mathrm{KO}$ & Forest & 5.0 & 6.3 & 14 & 50 & 990 & 170 & 75 & 15 & 10 \\
\hline MB & Blueberry & 4.5 & 6.1 & 96 & 40 & 191 & 53 & 86 & 9 & 5 \\
\hline $\mathrm{MB}$ & Forest & 3.9 & 11.1 & 17 & 35 & 48 & 27 & 79 & 13 & 8 \\
\hline \multirow[t]{2}{*}{ Means } & Blueberry & $4.6 \mathrm{a}^{\mathrm{y}}$ & $4.9 \mathrm{a}$ & $102 \mathrm{a}$ & $47 \mathrm{a}$ & $278 \mathrm{a}$ & $90 a$ & $86 a$ & $9 \mathrm{a}$ & $6 a$ \\
\hline & Forest & $4.5 \mathrm{a}$ & $5.8 \mathrm{a}$ & $20 \mathrm{~b}$ & $29 \mathrm{~b}$ & $278 \mathrm{a}$ & $58 \mathrm{a}$ & $85 \mathrm{a}$ & $8 \mathrm{a}$ & $5 \mathrm{a}$ \\
\hline
\end{tabular}

${ }^{\mathrm{y}}$ See Materials and Methods for description.

${ }^{\mathrm{y}}$ Mean separation by paired $t$ test $(P=0.05)$. See materials and methods for details. 
determinations, $10 \mathrm{~g}$ of sieved, field-moist soil was placed in a 250$\mathrm{mL}$ Erlenmeyerflask containing $100 \mathrm{~mL}$ of a solution containing 1.5 mM of $\mathrm{NH}_{4}^{+}$and $1 \mathrm{~mm}$ of $\mathrm{PO}_{4}{ }^{3-}$. Three flasks of each soil served as replications. Flasks were sponge-stoppered and agitated for $24 \mathrm{~h}$ on an orbital shaker at $180 \mathrm{rpm}$. Samples were removed from each flask after 2, 6, 10, 20, and $24 \mathrm{~h}$ of incubation and centrifuged at $8000 g_{\mathrm{n}}$ for $10 \mathrm{~min}$. The supernatant was decanted into polypropylene scintillation vials, preserved with chloroform $\left(2 \mathrm{~mL}\right.$ of $\mathrm{CHCl}_{3} / \mathrm{L}$ of sample solution) and frozen at $-20^{\circ} \mathrm{C}$ until $\mathrm{NO}_{3}{ }^{-}-\mathrm{N}$ analysis was conducted. The hourly rate of $\mathrm{NO}_{3}{ }^{-}-\mathrm{N}$ production $(\mathrm{mg} \mathrm{N} / \mathrm{L})$ was calculated by linear regression of $\mathrm{NO}_{3}^{-}-\mathrm{N}$ concentration versus time and converted to per unit dry soil $\left(\mathrm{mg} \cdot \mathrm{kg}^{-1}\right)$.

NITRIFIER POPULATIONS. Nitrifier populations in the 1999 sampled

Fig. 1. Changes in fertilizer derived $\mathrm{NO}_{3}{ }^{-} \mathrm{N}$ levels following addition of ${ }^{15} \mathrm{~N}-$ enriched $\left(\mathrm{NH}_{4}\right)_{2} \mathrm{SO}_{4}\left(\mathrm{~N}\right.$ at $35.5 \mathrm{mg} \cdot \mathrm{kg}^{-1}$ soil) to blueberry and forest soils sampled from seven Michigan farms in 1996. Vertical bars represent $+\mathrm{SE}(\mathrm{n}=3)$. soils were determined using the most probable number method (Rowe et al., 1977). Two replicate samples of each soil, consisting of $10 \mathrm{~g}$ moist soil, were blended with $190 \mathrm{~mL} 100 \mathrm{~mm}$ phosphate buffer (pH 7) in a Waring Blender (Waring Products Company, Winsted, Conn.). Coarse particles were allowed to settle for $1 \mathrm{~min}$, then $10 \mathrm{~mL}$ of the slurry was transferred to a sterile plastic tray for further dilution in the microtiter plates. Before inoculation, all wells of the microtiter plates were filled with $100 \mathrm{~mL}$ of $1 \times$ Schmidt and Belser (1994) medium. A multichannel pipettor was used to transfer eight $100 \mathrm{~mL}$ aliquots from the plastic tray to the first row of wells in the microtiter plates, mixed well with the medium, and then 100 $\mathrm{mL}$ of this mixture was transferred to the next row of wells, thus making a 1:2 dilution. A series of 12 twofold dilutions (equal to one microtiter plate) were made after the first 1:20 dilution in the blender.

The inoculated plates were double wrapped in plastic with a moist towel to help maintain moisture levels and then incubated in the dark at $25^{\circ} \mathrm{C}$ for 8 weeks. Uninoculated microtiter plates kept under the same condi-
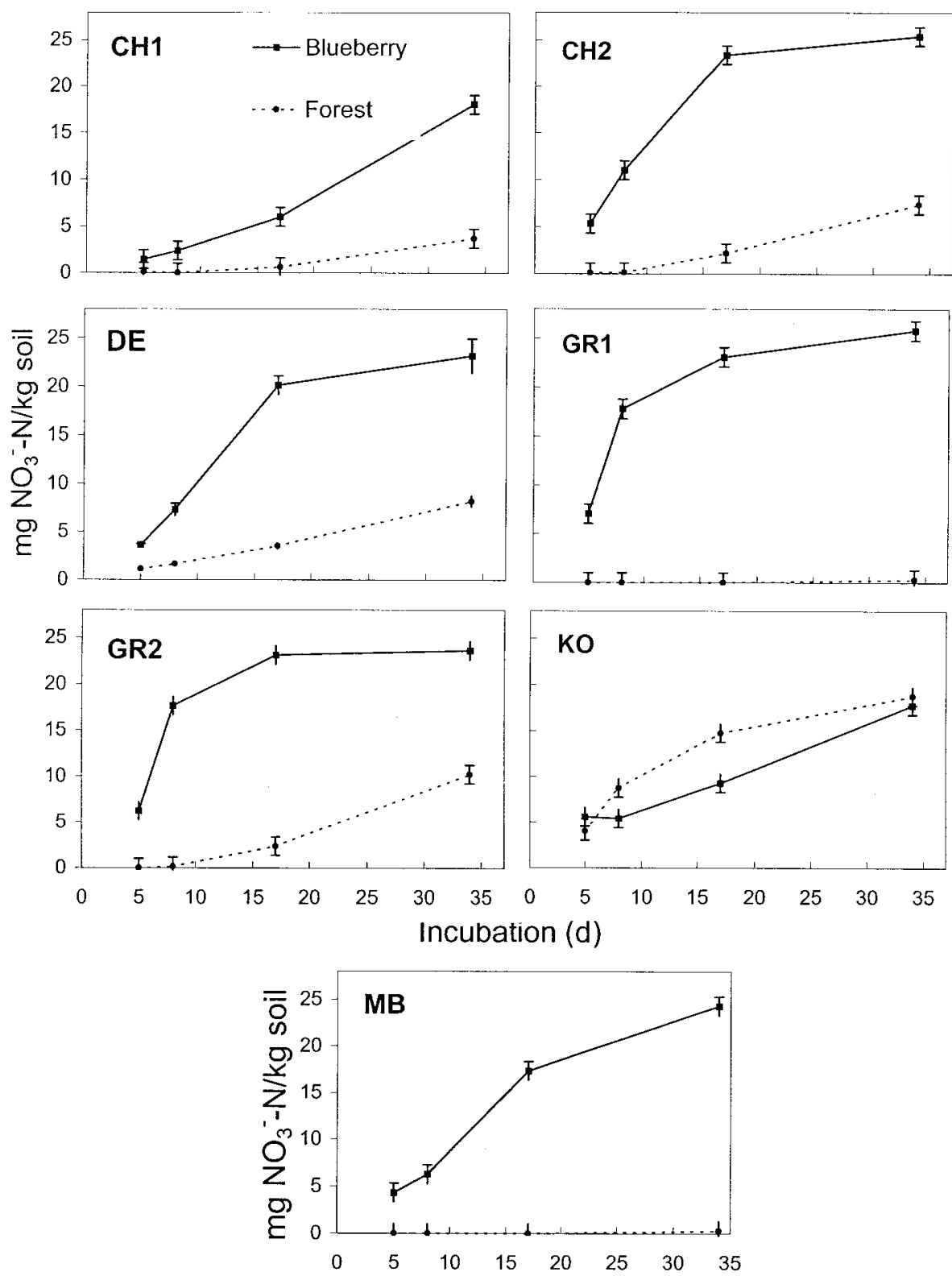

Incubation (d) tions were used as controls. After 8 weeks, each plate was checked for the presence of $\mathrm{NO}_{3}^{-}$and/or $\mathrm{NO}_{2}^{-}$by adding an indicator $(0.2$ $\mathrm{g}$ of diphenylamine in $100 \mathrm{~mL}$ of concentrated $\mathrm{H}_{2} \mathrm{SO}_{4}$ ) (Rowe et al., 1977). A blue color reaction was scored as positive. Two replicates of each soil were measured.

BaCterial populations. Total bacterial populations, cell sizes, and biomass were determined in the 1999 sampled soils using the methods of Bloem et al. (1995). Three replicate $10 \mathrm{~g}$ samples of each soil were blended in $190 \mathrm{~mL}$ of filtered, distilled water for $1 \mathrm{~min}$. The coarse particles were allowed to settle for $30 \mathrm{~s}$ and $20 \mathrm{~mL}$ bulk samples were placed in sterile tubes and treated with $0.1 \mathrm{~mL}$ formalin as a preservative. The samples were vortexed and $4 \mathrm{~mL}$ aliquots of each were placed in $6 \mathrm{~mm}$ wells on slides (Bellco Glass, Inc., Vineland, N.J.) and allowed to air dry completely. The dried smears were then flooded with a $8 \mathrm{~mL}$ DTAF [5-(4,6dichlorotiazin-2-yl) aminofluoroscein; Sigma Chem. Co., St. Louis] stain solution $(2 \mathrm{mg}$ DTAF in $10 \mathrm{~mL}$ of a buffer solution consisting of $0.05 \mathrm{M} \mathrm{Na}_{2} \mathrm{HPO}_{4}$ and $0.85 \% \mathrm{NaCl}$, adjusted to $\mathrm{pH}$ 9) for $1 \mathrm{~h}$ at $20^{\circ} \mathrm{C}$ in a covered container with wet tissue. The slides were rinsed three times for 20 min with the $\mathrm{Na}_{2} \mathrm{PO}_{4}$ $\mathrm{NaCl}$ buffer solution and finally briefly with water. After air drying, a cover slip was mounted with a small drop of immersion oil. The slides were stored in the dark at $20^{\circ} \mathrm{C}$ until observation.

Counts were performed with a $63 \times$ oil immersion objective lens and $1.6 \times$ zoom setting (total magnification $\approx 1000 \times$ ) using a LeitzOrthoplan 2epifluorescence microscope, a Lep HBO 50 mercury lamp, and a Leitz I3 filterblock (BP 450-490 excitation filter, RKP 510 beam splitter, and LP 515 suppression filter) (Leica Microsystems, Wetzlar, Germany). A charge-coupled device camera 
Table 2. Effect of site and cropping history (blueberry vs. forest) on fertilizer derived and soil derived (native) $\mathrm{NO}_{3}{ }^{-}-\mathrm{N}, \mathrm{NH}_{4}{ }^{+}-\mathrm{N}$, and total $\mathrm{N}$ at the end of a $34 \mathrm{~d}$ incubation.

\begin{tabular}{|c|c|c|c|c|c|c|c|}
\hline \multirow{2}{*}{$\begin{array}{l}\text { Study } \\
\text { site }^{\mathrm{z}}\end{array}$} & \multirow[b]{2}{*}{ Cropping } & \multicolumn{3}{|c|}{ Fertilizer derived N (mg/kg soil) } & \multicolumn{3}{|c|}{ Soil derived $\mathrm{N}\left(\mathrm{mg} \cdot \mathrm{kg}^{-1}\right.$ soil $)$} \\
\hline & & $\mathrm{NH}_{4}^{+}-\mathrm{N}$ & $\mathrm{NO}_{3}^{-}-\mathrm{N}$ & Total N & $\mathrm{NH}_{4}^{+}-\mathrm{N}$ & $\mathrm{NO}_{3}^{-}-\mathrm{N}$ & Total N \\
\hline \multirow[t]{2}{*}{$\overline{\mathrm{CH} 1}$} & Blueberry & 0.2 & 18.0 & 38.7 & 2.0 & 29.0 & 1787 \\
\hline & Forest & 11.6 & 3.7 & 28.5 & 14.0 & 4.3 & 821 \\
\hline \multirow[t]{2}{*}{$\mathrm{CH} 2$} & Blueberry & 0.1 & 25.4 & 28.9 & 2.1 & 30.7 & 1368 \\
\hline & Forest & 6.4 & 7.4 & 31.8 & 12.5 & 13.0 & 1641 \\
\hline \multirow[t]{2}{*}{$\mathrm{DE}$} & Blueberry & 0.1 & 23.1 & 36.3 & 1.3 & 40.0 & 2633 \\
\hline & Forest & 9.5 & 8.2 & 46.7 & 13.6 & 11.0 & 2305 \\
\hline \multirow[t]{2}{*}{ GR1 } & Blueberry & 0.0 & 25.8 & 44.9 & 1.3 & 26.8 & 1620 \\
\hline & Forest & 11.9 & 0.3 & 39.2 & 23.5 & 0.5 & 1758 \\
\hline \multirow[t]{2}{*}{ GR2 } & Blueberry & 0.0 & 23.6 & 43.1 & 1.0 & 25.7 & 1879 \\
\hline & Forest & 4.1 & 10.2 & 35.5 & 11.4 & 17.5 & 1541 \\
\hline \multirow[t]{2}{*}{$\mathrm{KO}$} & Blueberry & 6.7 & 17.8 & 45.2 & 11.4 & 40.0 & 1350 \\
\hline & Forest & 1.6 & 18.7 & 39.0 & 10.3 & 33.6 & 2521 \\
\hline \multirow[t]{2}{*}{ MB } & Blueberry & 0.1 & 24.3 & 34.0 & 1.6 & 26.1 & 2052 \\
\hline & Forest & 8.7 & 0.3 & 28.8 & 29.2 & 0.4 & 3161 \\
\hline \multicolumn{8}{|c|}{ Significance $\left(\operatorname{LSD}_{0.05}\right)$} \\
\hline Site $(\mathrm{S})$ & & $* *$ & $* *$ & $*$ & $*$ & $*$ & $* * *$ \\
\hline Cropping (C) & & $* * *$ & $* * *$ & NS & $* * *$ & $* *$ & NS \\
\hline $\mathrm{S} \times \mathrm{C}$ & & ${ }^{* *}(3.8)$ & ${ }^{* * *}(10.7)$ & NS & $* *(6.6)$ & ${ }^{* * *}(12.5)$ & ${ }^{* * *}(1890)$ \\
\hline
\end{tabular}

${ }^{\mathrm{z}}$ See materials and methods for details.

Ns,*,**,*** Nonsignificant or significant at $P<0.05,0.01$, or 0.001 , respectively. Numbers in parentheses are LSD values $(0.05)$ for $\mathrm{S} \times \mathrm{C}$ interaction.

(Princeton Instruments, Trenton, N.J.) was used to capture random images of each sample and transferred to a Power Macintosh 7100/ 66 via an ST135 detector/controller and GPIB interface card (Natl. Instruments, Austin, Texas). The images were then analyzed by IP Lab Spectrum image analysis software (Signal Analytics Corp., Vienna, Va.).

Data were subjected to analysis of variance using SAS protocals (SAS Inst., Inc., Cary, N.C.). A split-split-plot design was used for the labeled $\mathrm{N}$ incubation study, with the seven sites serving as main plots, cropping history (blueberry cultivated or forest) as subplots, and sampling time $(5,8,17$, and $30 \mathrm{~d}$ after treatment) as subsubplots. Data from the slurry incubations and bacterial populations were analyzed as a split plot with the five sites serving as main plots and cropping history as subplots.

\section{Results}

Labeled N Nitrification. Comparisons of selected chemical and physical characteristics of soils collected in 1996 (Table 1) indicated that blueberry soils contained higher levels of $\mathrm{P}$ and $\mathrm{K}$ than forest soils. The average $\mathrm{C}: \mathrm{N}$ ratio of forest soils (17.3) was not statistically different than that of cultivated soils (15.5).

ANOVA indicated highly significant $(P<0.0001)$ effects of sampling site, cropping (blueberry vs. forest), sampling time, and all interactions with respect to levels of fertilizer derived and total $\mathrm{NO}_{3}-$ ${ }^{-} \mathrm{N}$, and fertilizer derived and total $\mathrm{NH}_{4}{ }^{+}-\mathrm{N}$. Fertilizer derived $\mathrm{NO}_{3}{ }^{-}$ -N accumulated more rapidly in the blueberry soils than adjacent forest soils from all but the $\mathrm{KO}$ site, where the blueberry and forest soils accumulated fertilizer derived $\mathrm{NO}_{3}{ }^{-}-\mathrm{N}$ at similar rates (Fig. 1). Total $\mathrm{NO}_{3}^{-}-\mathrm{N}$ (native plus labeled) accumulation followed similar patterns (data not presented). By the end of the $34 \mathrm{~d}$ incubation, all blueberry soils except that from the $\mathrm{KO}$ site contained higher fertilizer derived and total $\mathrm{NO}_{3}{ }^{-}-\mathrm{N}$ levels than the corresponding forest soils (Table 2).

Fertilizer derived $\mathrm{NH}_{4}{ }^{+}-\mathrm{N}$ levels declined at rates inversely proportion to $\mathrm{NO}_{3}{ }^{-}-\mathrm{N}$ accumulation (data not presented), and ap- proached zero in most blueberry soils after $34 \mathrm{~d}$ of incubation (Table 2). By day 17, the $\mathrm{CH} 1, \mathrm{CH} 2, \mathrm{DE}, \mathrm{GR} 1, \mathrm{GR} 2, \mathrm{KO}$ and MB blueberry soils contained $6.1,0.5,1.0,0.1,1.3,4.0$, and $4.0 \mathrm{mg}$ fertilizer derived $\mathrm{NH}_{4}{ }^{+}-\mathrm{N} / \mathrm{kg}$ soil, respectively, while levels in the forest soils from the same sites were 14.1, 9.8, 12.1, 13.0, 7.3, 14.6, and $9.0 \mathrm{mg}$. Since fertilizer derived $\mathrm{NH}_{4}{ }^{+}-\mathrm{N}$ levels in some soils were low enough after $17 \mathrm{~d}$ to limit subsequent $\mathrm{NO}_{3}{ }^{-}$production, net nitrification potentials were compared based on the slopes of linear regressions of fertilizer derived $\mathrm{NO}_{3}{ }^{-}-\mathrm{N}$ over time between days 5 and 17 (Fig. 2). All blueberry soils exhibited higher net nitrification potentials than adjacent forest soils, except for those from the KO site, where the forest soil had a higher nitrification potential than the blueberry soil (Fig. 2).

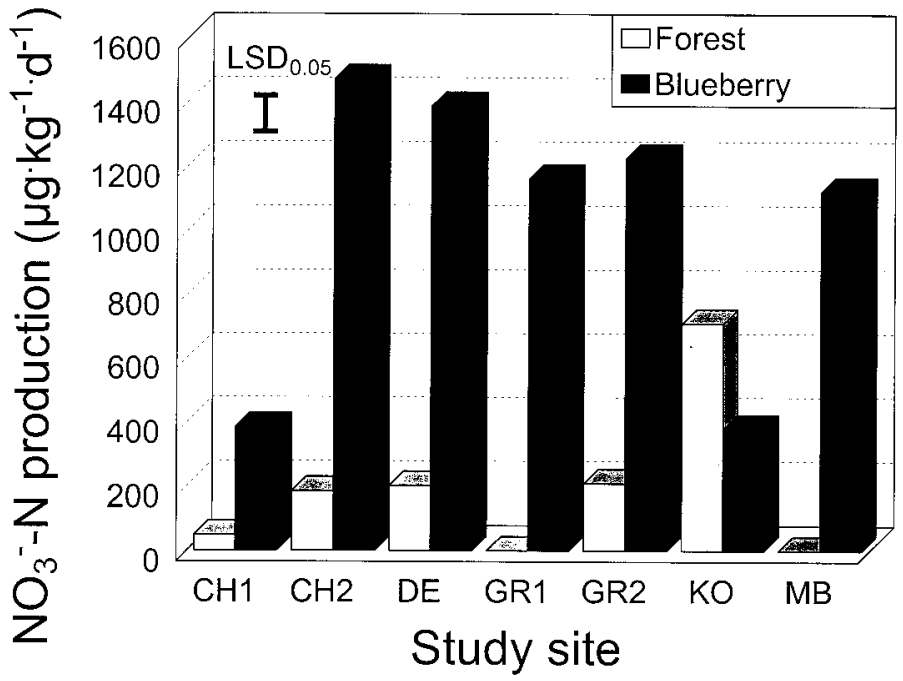

Fig. 2. Daily fertilizer derived $\mathrm{NO}_{3}{ }^{-}-\mathrm{N}$ production following addition of ${ }^{15} \mathrm{~N}-$ enriched $\left(\mathrm{NH}_{4}\right)_{2} \mathrm{SO}_{4}$ to blueberry and forest soils sampled in 1996. Rates were derived by regressing fertilizer derived $\mathrm{NO}_{3}{ }^{-}-\mathrm{N}$ concentrations over time between day 5 and day 17 following $\left(\mathrm{NH}_{4}\right)_{2} \mathrm{SO}_{4}$ addition. 


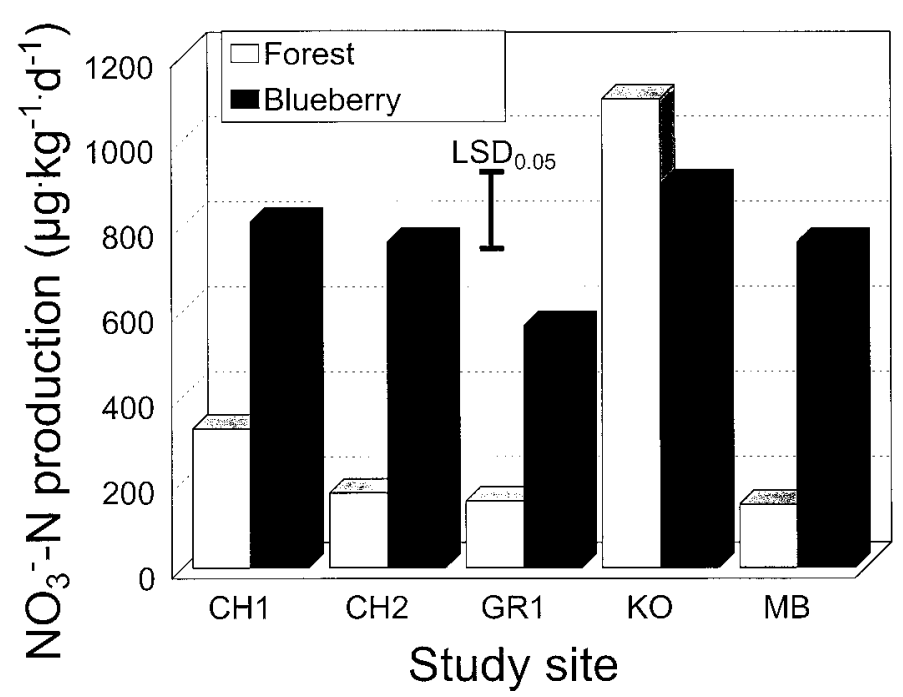

Fig. 3. Daily $\mathrm{NO}_{3}{ }^{-}-\mathrm{N}$ production/kg soil during a 24-h slurry incubation of five blueberry and five forest soils sampled from Michigan farms in 1999. Rates were derived by regressing changes in $\mathrm{NO}_{3}{ }^{-} \mathrm{N}$ concentrations over time.

Blueberry and forest soils contained similar amounts of total fertilizer-derived $\mathrm{N}$ after $34 \mathrm{~d}\left(35.2\right.$ and $37.5 \mu \mathrm{g} \cdot \mathrm{g}^{-1}$ dry soil, respectively), but significantly more $(P=0.033)$ of the fertilizer derived $\mathrm{N}$ was present in organic forms in the forest soils $(56 \%)$ than the blueberry soils (32\%) (Table 2).

SLURRY NITRIFICATION. ANOVA of nitrification rates indicated that the effects of the site, cropping (blueberry vs. forest), and the site $\times$ cropping interaction were highly significant $(P<0.001)$. Blueberry soils from the $\mathrm{CH} 1, \mathrm{CH} 2, \mathrm{GR} 1$, and $\mathrm{MB}$ sites exhibited higher net nitrification rates than corresponding forest soils, whereas nitrification rates in the blueberry and forest soils from the $\mathrm{KO}$ site did not differ (Fig. 3).

Microbiological STUDies. Total bacteria numbers, average bacterial cell volume, and total bacterial biomass $C$ varied significantly between sites (Table 3), but were not consistently affected by cropping history (blueberry vs. forest). The one exception was the $\mathrm{CH} 1$ site, where total bacteria numbers and biomass $\mathrm{C}$ were higher in the blueberry than the forest soil (Table 3 ). The population of autotrophic nitrifying bacteria did not vary significantly between sites, but was significantly higher in blueberry soils $\left(3.4 \times 10^{3} / \mathrm{g}\right.$ soil $)$ than forest soils $\left(6.1 \times 10^{2}\right)$.

\section{Discussion}

Two incubation procedures indicated that net nitrification potential of blueberry soils is higher than that of most similar forest soils. Most blueberry soils also contained greater numbers of autotrophic nitrifying bacteria compared to the forest soils. Higher nitrifier numbers were also observed in soils used for conventional crop rotations compared to similar nontilled grassland soils (Bruns et al., 1999). Other measures of bacterial activity or health (total bacteria numbers, average bacterial cell volumes, and bacterial biomass $\mathrm{C}$ ) were similar in blueberry and forest soils, and were comparable to values reported for other soils (Bruns et al., 1999).

The low nitrification rates in most forest soils did not appear to result from limited availability of $\mathrm{NH}_{4}{ }^{+}$substrate. Each forest soil in the labeled $\mathrm{N}$ incubation study, except that from the $\mathrm{KO}$ site, contained more total and fertilizer derived $\mathrm{NH}_{4}{ }^{+}-\mathrm{N}$ than the corresponding blueberry soils after 17 and $34 \mathrm{~d}$ of incubation, indicating that $\mathrm{NO}_{3}{ }^{-}-\mathrm{N}$ production in forest soils was not limited by $\mathrm{NH}_{4}{ }^{+}$ supply.

On average, forest soils immobilized fertilizer $\mathrm{N}$ more rapidly than blueberry soils. After $34 \mathrm{~d}$ of incubation, $56 \%$ of the fertilizer $\mathrm{N}$ in forest soils was in organic forms, compared to $32 \%$ in the blueberry soils (Table 2). Since the forest collection areas had not been fertilized with $\mathrm{N}$, applied $\mathrm{N}$ was expected to be immobilized more rapidly in forest than the blueberry soils. Soils with high $\mathrm{C}: \mathrm{N}$ ratios tend to immobilize added $\mathrm{N}$ more rapidly than those with lower ratios. The average $\mathrm{C}: \mathrm{N}$ ratio of forest soils (17.3) was not statistically different than that of blueberry soils (15.5). However, soil $\mathrm{C}$ levels in this study were only estimated by multiplying soil organic matter content by a common conversion factor (1.724).

The incubation procedures used in this study measured net, rather than gross, nitrification rates because they did not account for $\mathrm{NO}_{3}{ }^{-}$removal. Recent work indicates that microorganisms in some forest soils immobilize substantial amounts of $\mathrm{NO}_{3}{ }^{-}$(Hart et al., 1994; Stark and Hart, 1997) so that net nitrification rates may underestimate gross nitrification rates. The low $\mathrm{NO}_{3}^{-}-\mathrm{N}$ levels in

Table 3. Total bacteria population, average cell volume, bacterial biomass, and autotrophic nitrifying bacteria populations in blueberry and forest soils sampled from Michigan sites in 1999.

\begin{tabular}{|c|c|c|c|c|c|}
\hline $\begin{array}{l}\text { Study } \\
\text { site }^{\mathrm{z}}\end{array}$ & Cropping & $\begin{array}{l}\text { Bacteria cells } \\
\left(10^{9} / \mathrm{g} \text { soil }\right)\end{array}$ & $\begin{array}{l}\text { Cell volume } \\
\qquad\left(\mu \mathrm{m}^{3}\right)\end{array}$ & $\begin{array}{l}\text { Bacterial biomass } \\
\text { carbon }\left(\mathrm{mg} \cdot \mathrm{g}^{-1} \text { soil }\right)\end{array}$ & $\begin{array}{c}\text { Nitrifying bacteria } \\
\text { (cells/g soil) }\end{array}$ \\
\hline \multirow[t]{2}{*}{$\overline{\mathrm{CH} 1}$} & Blueberry & 6.1 & 0.071 & 88 & 2,080 \\
\hline & Forest & 2.0 & 0.072 & 28 & 960 \\
\hline \multirow[t]{2}{*}{$\mathrm{CH} 2$} & Blueberry & 5.7 & 0.074 & 85 & 1,230 \\
\hline & Forest & 5.9 & 0.084 & 98 & 760 \\
\hline \multirow[t]{2}{*}{ GR1 } & Blueberry & 2.9 & 0.072 & 41 & 5,010 \\
\hline & Forest & 2.3 & 0.077 & 35 & 50 \\
\hline \multirow[t]{2}{*}{$\mathrm{KO}$} & Blueberry & 6.6 & 0.094 & 123 & 5,350 \\
\hline & Forest & 7.6 & 0.094 & 143 & 1,200 \\
\hline \multirow[t]{2}{*}{ MB } & Blueberry & 2.9 & 0.071 & 41 & 3,540 \\
\hline & Forest & 2.8 & 0.084 & 46 & 60 \\
\hline \multicolumn{6}{|c|}{ Significance $\left(\operatorname{LSD}_{0.05}\right)$} \\
\hline Site $(\mathrm{S})$ & & $* * *$ & $* * *(0.011)$ & $* * *$ & NS \\
\hline Cropping (C) & & NS & NS & NS & $* *(620)$ \\
\hline $\mathrm{S} \times \mathrm{C}$ & & $*(2.0)$ & NS & $*(11)$ & NS \\
\hline
\end{tabular}

${ }^{\mathrm{z}}$ See materials and methods for details.

Ns, ${ }^{* * *, * * *}$ Nonsignificant or significant at $P<0.05,0.01$, or 0.001 , respectively. Numbers in parentheses are LSD values $(0.05)$. 
most forest soils in our study did not appear to result from $\mathrm{NO}_{3}{ }^{-}$ immobilization. If the low $\mathrm{NO}_{3}^{-}-\mathrm{N}$ levels in our forest soils resulted from microbial immobilization, fertilizer derived $\mathrm{NH}_{4}{ }^{+}-\mathrm{N}$ levels would have been depleted at more rapid rates in forest soils. The fact that forest soils both accumulated $\mathrm{NO}_{3}{ }^{-}-\mathrm{N}$ and lost $\mathrm{NH}_{4}{ }^{+}-\mathrm{N}$ more slowly than blueberry soils indicates that the $\mathrm{NO}_{3}{ }^{-}-\mathrm{N}$ levels in forest soils were not low due to immobilization.

The amount of fertilizer-derived $\mathrm{N}$ present at the end of the incubation (35.2 and $37.5 \mu \mathrm{g} \mathrm{N} / \mathrm{g}$ dry soil in forest and blueberry soils, respectively) was $5 \%$ to $12 \%$ greater than the $33.5 \mu \mathrm{g} \mathrm{N} / \mathrm{g}$ dry soil added initially. This small difference may reflect sampling and measurement errors. The fact that the final fertilizer-derived $\mathrm{N}$ was higher than the application rate suggests that losses of fertilizerderived $\mathrm{N}$ via denitrification were negligible.

Why net nitrification in the $\mathrm{KO}$ forest soil was so high compared to other forest soils and the KO blueberry soil is not clear. The KO forest soil had the highest net nitrification rate of any forest soil in both incubation tests, and a higher nitrification rate than the $\mathrm{KO}$ blueberry soil in the labeled $\mathrm{N}$ incubation test(Fig. 2). The KO forest soil also had high nitrifier numbers relative to other forest soils (Table 3), and both KO soils had relatively high total bacteria counts, average cell size, and bacterial biomass $\mathrm{C}$ (Table 3 ), indicating that these soils supported high overall bacterial populations. The KO soils also differed from most other soils in that the silt and clay contents were unusually high (Table 2). Nitrification rates of some soils are positively correlated with clay quantity (Neill et al., 1997) and type (Sarathchandra, 1978). The KO forest site was similar to other forest sites in terms of maximum estimated tree age (about 60 years) and species composition [mixed maple (Acer L.) and oak (Quercus L) sp.].

Although autotrophic nitrifying bacteria are inhibited by acidic conditions in culture (Weber and Gainey, 1962), no relationship between $\mathrm{pH}$ and net nitrification rate was apparent in this study. Mean $\mathrm{pH}$ of blueberry soils (4.6) was not significantly different from that of forest soils (4.5), when compared with a paired $t$ test. Also, soil $\mathrm{pH}$ was not significantly correlated with nitrification rates (Fig. 2) of blueberry soils ( $r=0.738, \mathrm{n}=7)$, forest soils $(r=0.44, \mathrm{n}$ $=7)$, or blueberry and forest soils combined ( $r=0.52, \mathrm{n}=14)$.

Why nitrifier populations and nitrification rates were higher in most blueberry soils is not clear. We speculate that the annual use of $\mathrm{NH}_{4}{ }^{+}$fertilizers induced a larger nitrifier population in these blueberry soils, since enhanced nitrifier populations and/or nitrification capacity have been associated with $\mathrm{NH}_{4}{ }^{+}$fertilization in other cropping (Bruns et al., 1999; Eaton and Patriquin, 1988; Tabatabai et al., 1992) and forest systems (Martikainen, 1985). However, the soils in these blueberry sites were altered in other ways that could conceivably influence nitrifier populations and nitrification potentials. Soil P and K were higher in blueberry soils than the corresponding forest soils (Table 2), presumably due to past fertilization, and nitrification rates in some forest soils are positively correlated with soil P content (Martikainen, 1984; Pastor et al., 1984). Blueberry sites are also cultivated prior to planting, and the soil beneath the plants that was sampled in this study may or may not have been cultivated again after the initial disturbance. Cultivation stimulates organic matter oxidation and $\mathrm{N}$ mineralization (Reinhorn and Avnimelech, 1974), and nitrification rates in some ecosystems are increased initially, then decline with time after disturbance (Rice and Pancholy, 1972). Less organic debris was observed on the surface of these blueberry soils compared to the forest soils, and $\mathrm{N}$ mineralization and nitrification rates in forest soils are influenced by the composition and quantity of litter (Zak and Pregitzer, 1990). Nitrification may also have been influenced by drainage differ- ences. Since these soils are either poorly drained or somewhat poorly drained, drainage is often improved by surface ditching or tiling when developing sites for blueberry culture.

Data herein indicate that an increase in nitrifying bacteria populations and nitrification capacity usually accompany blueberry culture. The practical significance is that optimum timing of fertilization may depend on the nitrification capacity. On soils that nitrify readily, multiple applications at lower $\mathrm{N}$ rates may reduce leaching losses and increase fertilizer use efficiency. A single application may be as effective as multiple applications in soils with low nitrification capacities since these soils may retain $\mathrm{N}$ in the less leachable $\mathrm{NH}_{4}{ }^{+}$form. Blueberry producers have observed that new plants grow more slowly when replanted on old blueberry sites compared to virgin soils. Perhaps one factor contributing to slow growth on replanted sites is higher nitrification rates which increase leaching losses and reduce efficiency of $\mathrm{N}$ fertilizer use. Since over $40 \%$ of the Michigan blueberry acreage is older than 25 years (Fedewa et al., 1998), and much of the younger acreage is likely to have been replanted to blueberries, increased nitrification rates may be common in the industry.

\section{Literature Cited}

Bloem, J., M. Veninga, and J. Sheperd. 1995. Fully automatic determination of soil bacterium numbers, cell volumes, and frequencies of dividing cells by confocal laser scanning microscopy and image analysis. Appl. Environ. Microbiol. 61:926-936

Brooks, P.D., J.M. Stark, B.B. McInteer, and T. Preston. 1989. Diffusion method to prepare soil extracts for automated nitrogen-15 analysis. Soil Sci. Soc. Amer. Proc. 53:1707-1711.

Bruns, M.A., J.R. Stephen, G.A. Kowalchuk, J.I. Prosser, and E.A. Paul. 1999. Comparative diversity of ammonia oxidizer 16S rRNA gene sequences in native, tilled, and successional soils. Appl. Envir. Microbiol. 65:2994-3000.

Combs, S.M. and M.V. Nathan. 1998. Soil organic matter. In: J.R. Brown (ed.). Recommended chemical soil test procedures for the North Central Region. North Central Reg. Res. Publ. 221. Mo. Agr. Expt. Station, Columbia.

Dancer, W.S., L.A. Peterson, and G. Chesters. 1973. Ammonification and nitrification of $\mathrm{N}$ as influenced by soil $\mathrm{pH}$ and previous $\mathrm{N}$ treatments. Soil Sci. Soc. Amer. Proc. 37:67-69.

De Boer, W., P.J. Klein Gunnewiek, and S.R. Troelstra. 1990. Nitrification in Dutch heathland soils. II. Characteristics of nitrate production. Plant Soil 127:193-200.

De Boer, W., P.J. Klein Gunnewiek, M. Veenhuis, E. Bock, and H.J. Laanbroek. 1991. Nitrification at low pHby aggregated chemolithotrophic bacteria. Appl. Environ. Microbiol. 57:3600-3604.

Eaton, L.J. and D.G. Patriquin. 1988. Inorganic nitrogen levels and nitrification potential in lowbush blueberry soils. Can. J. Soil Sci. 68:6375.

Fedewa, D.J., S.J. Pscodna, M. Saffell, and M. Espie. 1998. Michigan rotational survey, fruit. Mich. Agr. Stat. Serv., Mich. Dept. Agr. Lansing.

Hankinson, T.R. andE.L. Schmidt. 1984. Examination of an acid forest soil for ammonia- and nitrite-oxidizing autotrophic bacteria. Can.J.Microbiol. 30:1123-1132.

Hanson, E.J. and J. F. Hancock. 1996. Managing the nutrition of highbush blueberries. Mich. State Univ. Ext. Bul. E-2011.

Hanson, E.J. and M. Mandujano. 1997. Nitrification rates in Michigan blueberry soils. Acta Hort. 446:507-512.

Harris, D. and E.A. Paul. 1989. Automated analysis of $15 \mathrm{~N}$ and $14 \mathrm{C}$ in biological samples. Commun. Soil Sci. Plant Anal. 20:935-947.

Hart, S.C., J.M. Stark, E.A. Davidson, and M.K. Firestone. 1994. Nitrogen mineralization, immobilization, and nitrification, p. 985-1018. In: J.M. Bigham (ed.). Methods of soil analysis: part 2-Microbiological and biochemical properties. Soil Sci. Soc. Amer., Madison, Wis.

Herath, H.M.E. and G.W.Eaton. 1968. Some effects of water table, pH, and nitrogen fertilization upon growth and composition of highbush blue- 
berry. Proc. Amer. Soc. Hort. Sci. 92:274-283.

Martikainen, P.J. 1984. Nitrification in two coniferous forest soils after different fertilization treatments. Soil Biol. Biochem. 16:577-582.

Martikainen, P.J. 1985. Numbers of autotrophic nitrifiers and nitrification in fertilized forest soil. Soil Biol. Biochem. 17:245-248.

Morrill, L.G. and J.E. Dawson. 1967. Patterns observed for the oxidation of ammonium to nitrate by soil organisms. Soil Sci. Soc. Amer. Proc. 31:757-760.

Neill, C., M.C. Piccolo, C.C. Cerri, P.A. Steudler, J.M. Melillo, and M. Brito. 1997. Net nitrogen mineralization and net nitrification rates in soils following deforestation for pasture across the southwestern Brazilian Amazon Basin landscape. Oecologia 110:243-252.

Nelson, D.W. and L.E. Sommers. 1982. Total carbon, organic carbon, and organic matter. In: A.L. Page (ed.). Methods of soil analysis: Part $2-$ Chemical and microbiological properties. $2^{\text {nd }}$ ed. Amer. Soc. Agron., Madison, Wis.

Pastor, J., J.D. Aber, C.A. McClaugherty, and J.M. Melillo. 1984 Aboveground production and $\mathrm{N}$ and $\mathrm{P}$ cycling along a nitrogen mineralization gradient on Blackhawk Island, Wisconsin. Ecology 65:256268.

Peterson, L.A., E.J. Stang, and M.N. Dana. 1988. Blueberry response to $\mathrm{NH}_{4}-\mathrm{N}$ and $\mathrm{NO}_{3}-\mathrm{N}$. J. Amer. Soc. Hort. Sci. 113:9-12.

Reinhorn, T. and Y. Avnimelech. 1974. Nitrogen release associated with the decrease in soil organic matter in newly cultivated soils. J. Environ. Qual. 3:118-121.

Rice, E.L. and S.K. Pancholy. 1972. Inhibition of nitrification by climax ecosystems. Amer. J. Bot. 59:1033-1040.

Robertson, G.P., E.A. Paul, and R.R. Harwood. 2000. Greenhouse gases in intensive agriculture: Contributions of individual gases to the radiative forcing of the environment. Science 289:1922-1925.

Rowe, R., R. Todd, and J. Waide. 1977. Microtechnique for most-probablenumber analysis. Appl. Environ. Microbiol. 33:675-680.

Sarathchandra, S.U. 1978. Nitrification activities of some New Zealand soils and the effect of some clay types on nitrification. N.Z. J. Agr. Res. 21:615-621.

Schmidt, E.L. and L.W. Belser. 1994. Autotrophic nitrifying bacteria, p. 159-177. In: J.M. Bigham (ed.). Methods of soil analysis: Part 2Microbiological and biochemical properties. Soil Sci. Soc. Amer., Madison, Wis.

Stark, J.M. and S.C. Hart. 1997. High rates of nitrification and nitrate turnover in undisturbed coniferous forests. Nature 385:61-64.

Stroo, H.F., T.M. Klein, and M. Alexander. 1986. Heterotrophic nitrification in an acid forest soil by an acid-tolerant fungus. Appl. Environ. Microbiol. 52:1107-1111.

Tabatabai, M.A., M.H. Fu, and N.T. Basta. 1992. Effects of cropping systems on nitrification in soils. Commun. Soil. Sci. Plant Anal. 23:18851891.

Throop, P.A. and E.J. Hanson. 1998. Nitrification and utilization of fertilizer nitrogen by highbush blueberries. J. Plant Nutr. 21: 1731-1742.

Watson, S.W. 1974. Gram-negative chemolithotrophic bacteria. Family I. p. 450-456. In: R.E. Buchanan and N.E. Gibbons (eds.). Bergey's manual of determinative bacteriology. 8th ed. Williams and Wilkins Co., Baltimore, $\mathrm{Md}$.

Weber, D.F. and P.L. Gainey. 1962. Relative sensitivity of nitrifying organisms to hydrogen ions in soils and in solutions. Soil Sci. 94:138145.

Zak, D.R. and K.S. Pregitzer. 1990. Spatial and temporal variability of nitrogen cycling in norther lower Michigan. For. Sci. 36:367-380. 